\title{
Pepper Stip: An Abiotic Disorder of Unknown Cause Affecting Pepper Fruit ${ }^{1}$
}

\author{
Camille Esmel McAvoy and Pamela Roberts ${ }^{2}$
}

\section{Introduction}

Pepper stip (meaning speck in German), also referred to as color speck or colour spotting outside the United States, is considered an abiotic (nonliving, i.e., of chemical, physical, or environmental origin) disorder from a physiological condition of pepper fruit (OMAFRA 2009; Savvas et al. 2008). The disorder is believed to be related to high calcium status, with levels of $\mathrm{NH}_{3}-\mathrm{N}$ and $\mathrm{K}$ playing a role. It was first described in the early 1970s by two separate researchers, Villalon (1975) and Eijsinga et al. (1973). The objective of this factsheet is to summarize known symptoms, causes, and potential environmental stressors that may result in stip development on peppers.

\section{Symptoms}

Stip is characterized by green to yellow or dark gray to black spots under the fruit epidermis (Fulton and Uchanski 2017; Seminis 2017). Spots may be grouped or single in formation (Figure 1). Damaged tissues have a collection of crystals (presumed to be oxalate) and ruptured cells deep in the pepper tissue but not in the epidermis (Aloni et al. 1994). A recently published study was not able to confirm this hypothesis of chelated oxalic acid being the main cause of pepper stip (Fulton et al. 2021). The authors did suggest that damage potentially could be due to nutrient assimilation and storage.

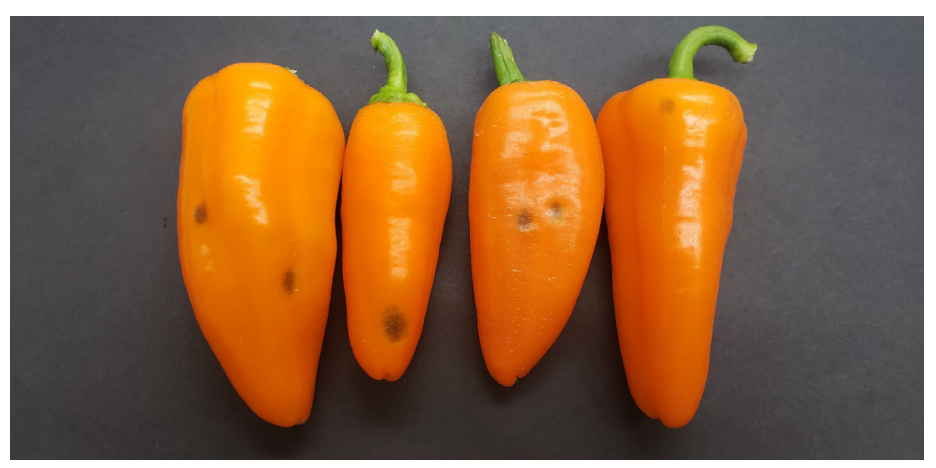

Figure 1. Pepper fruit grown in a greenhouse with symptoms of stip. Credits: Pamela Roberts, UF/IFAS

\section{Cause/Causes}

The disorder is difficult to predict because it is sporadic in nature. It is most observed in the late summer to fall (Seminis 2017) when pepper pods are most likely mature. Research has focused upon nutritional aspects of the disorder (Fulton and Uchanski 2017; Johnson 2012) as well as shading (Aloni et al. 1994; Jovicich et al. 2007). No one has yet conclusively found the factors that cause pepper stip to occur.

Despite the inconclusiveness of research, nutrients appear to be the largest factor involved in the occurrence of stip in peppers. Aloni et al. (1994) reported pepper fruits not accumulating calcium $(\mathrm{Ca})$ but found higher $\mathrm{Ca}$ content in only the affected portion of the fruit pericarp. This study further noted potassium $(\mathrm{K})$ and magnesium $(\mathrm{Mg})$ were not

1. This document is PP363, one of a series of the Plant Pathology Department, UF/IFAS Extension. Original publication date August 2021. Visit the EDIS website at https://edis.ifas.ufl.edu for the currently supported version of this publication.

2. Camille Esmel McAvoy, assistant research scientist, PhD, and Pamela D. Roberts, professor, Plant Pathology Department, UF/IFAS Southwest Florida Research and Education Center, Immokalee, FL 34142.

The Institute of Food and Agricultural Sciences (IFAS) is an Equal Opportunity Institution authorized to provide research, educational information and other services

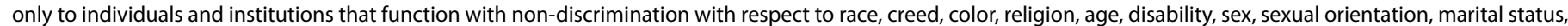

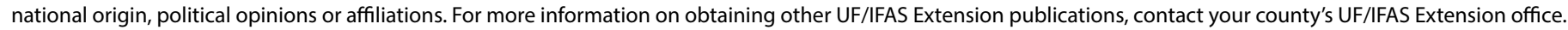
U.S. Department of Agriculture, UF/IFAS Extension Service, University of Florida, IFAS, Florida A \& M University Cooperative Extension Program, and Boards of County Commissioners Cooperating. Nick T. Place, dean for UF/IFAS Extension. 
accumulated in stip-affected tissue. It was suggested that increasing $\mathrm{N}$ supply inadvertently increased oxalate within the tissues to combat increasing cytosolic $\mathrm{pH}$ (Aloni et al. 1994). Similarly, de Kreij et al. (1992) found "gold specks" in tomato to be associated with excess $\mathrm{Ca}$ as deposits of calcium oxalate. The authors suggested that increased incidence of this disorder was related to high humidity and increased $\mathrm{Ca}$. While both of these factors are considered environmental conditions in Florida (i.e., subtropical climate and abundant levels of $\mathrm{Ca}$ in soils), manifestations of stip in pepper fields is inconsistent at best.

Further research found correlations between potassium (K) and calcium (Ca) content of pepper leaves and the manifestation of stip (Smith et al. 1999). Along with these correlations, the authors also found nitrogen $(\mathrm{N})$ content to be reduced in those cultivars resistant to the disorder. Aloni et al. (1994) had similar results where the variety that assimilated more $\mathrm{N}$ also had a higher percentage of stip-affected fruit. More recently, Fulton (2016) suggested that the causes of the disorder may not be a "resistance" vs. "susceptibility" factor for each variety, but rather that certain cultivars are more tolerant to particular environmental stressors.

Potential environmental stressors for inducing stip have been suggested as follows: limited photosynthetically active radiation (PAR) in shade environments (Aloni et al. 1994), decreasing solar radiation (Jovicich and Cantliffe 2007), temperature extremes (Silber et al. 2009; Cheewawiriyakul et al. 2006), and shortened day length at fruit maturity (Bosland and Votava 2000; Cheewawiriyakul et al. 2006). Even within the abovementioned studies, there is no clear consensus among researchers as to what observed symptoms characterize stip (Silber et al. 2009). Further research into inducing stip under controlled environmental conditions could resolve this.

Until further information is known about stip and the factors causing it, the following steps are recommended:

1. Reduce abiotic production stress as much as possible.

2. Choose varieties with known performance under conditions common to production season. If unknown, choose hybrid varieties over open pollinated (Hartz et al. 2008).

3. Scout and monitor for incidence of stip in chile pepper production when short days and cool temperatures occur near fruit maturity.

\section{References}

Aloni, B., L. Karni, I. Rylski, and Z. Zaidman. 1994.

"The Effect of Nitrogen Fertilization and Shading on the Incidence of 'Colour Spots' in Sweet Pepper (Capsicum annuum) Fruit.” J. Hort. Sci. 69 (4): 767-773. https://doi.org /10.1080/14620316.1994.11516511

Bosland, P. W., and E. J. Votava. 2000. Peppers: Vegetable and Spice Capsicums. Crop Production Science in Horticulture Series (Vol. 12). Oxon, UK: CABI Publishing.

Cheewawiriyakul, S., R. Chiang, K. Conn, B. Gabor, J. Kao, and R. Salati. 2006. Pepper and Eggplant Disease Guide: A Practical Guide for Seedmen, Growers, and Agricultural Advisors. Kevin Conn (Ed.). Woodland, CA: Seminis. https://santamariaseeds.com/wp-content/uploads/2016/10/ Pepper_Eggplant_Disease_Guide.pdf

Eijsinga, R. R. Rodenburg, and L.G. Uffelen. 1973. "Bitter Pit, a New Quality Problem in Red Peppers." Bedrijfsontwikkeling 4 (7/8): 733-734.

Fulton, J. C. 2016. "Chile Pepper Stip: A Physiological Disorder of Peppers.” M.S. Thesis. University of New Mexico.

Fulton, J. C., F. O. Holguin, R. L. Steiner, and M. E. Uchanski. 2021. "A Microscopic and Metabolic Description of Stip-Affected Tissue in New Mexico Pod-Type Pepper." J. Amer. Hort. Sci. 146 (3): 169-177. https://doi.org/10.21273/ JASHS05004-20

Fulton, J. C., and M. E. Uchanski. 2017. "A Review of Chile Pepper (Capsicum annuum) Stip: A Physiological Disorder of Peppers." HortSci 52 (1): 4-9. https://doi.org/10.21273/ HORTSCI11123-16

Hartz, T., M. Cantwell, and M. Lestrange. 2008. Bell Pepper Production in California. Publication 7217. University of California, Division of Agriculture and Natural Resources. https://doi.org/10.3733/ucanr.7217

Johnson, G. 2012. "Stip Disorder in Peppers." Weekly Crop Update. University of Delaware Cooperative Extension. https://sites.udel.edu/weeklycropupdate/?p=4780

Jovicich, E., D. J. Cantliffe, P. J. Stoffella, and D. Z. Haman. 2007. "Bell Pepper Fruit Yield and Quality as Influenced by Solar Radiation-Based Irrigation and Container Media in a Passively Ventilated Greenhouse." HortSci. 42 (3): 642-652. https://doi.org/10.21273/HORTSCI.42.3.642 
Ontario Ministry of Agriculture, Food and Rural Affairs (OMAFRA). 2009. “Colour Disorders.” In Ontario Crop IPM. Queen's Printer for Ontario. http://www.omafra.gov. on.ca/IPM/english/peppers/diseases-and-disorders/colourdisorders.html

Savvas, D., G. Ntatsi, and H. C. Passam. 2008. "Plant Nutrition and Physiological Disorders in Greenhouse Grown Tomato, Pepper, and Eggplant." Euro. J. Plant Sci Biotech. 2 (SI 1): 45-61.

Seminis. 2017. “Agronomic Spotlight: Pepper Stip.” https:// www.seminis-us.com/resources/agronomic-spotlights/ pepper-stip/

Silber, A., A. Bar-Tal, I. Levokvitch., M. Bruner, H. Yehezkel, D. Shmuel, S. Cohen. E. Matan, L. Karni, H. Aktas, E. Turhan, and B. Aloni. 2009. "Manganese Nutrition of Pepper (Capsicum annuum L.): Growth, Mn Uptake, and Fruit Disorder Incidence." Scientia Hort. 123:197-203.

https://doi.org/10.1016/j.scienta.2009.08.005

Smith, R., R. Mullen, and T Hartz. 1999. "Epidemiology and Control of Pepper Stip." HortSci. 34 (3): 441. https:// doi.org/10.21273/HORTSCI.34.3.441B 